\title{
Knowledge and correlates of use of safer conception methods among HIV-infected women attending HIV care in Uganda
}

Violet Gwokyalya ${ }^{\text {* }}$, Jolly Beyeza-Kashesya², John Baptist Bwanika', Joseph K. B. Matovu', Shaban Mugerwa ${ }^{3}$, Jim Arinaitwe ${ }^{3}$, Dickson Kasozi ${ }^{1}$, Justine Bukenya ${ }^{1}$, Rosemary Kindyomunda ${ }^{4}$, Glenn J. Wagner ${ }^{5}$, Fredrick E. Makumbi ${ }^{1}$ and Rhoda K. Wanyenze ${ }^{1}$

\begin{abstract}
Background: Many people living with HIV would like to have children but family planning (FP) services often focus on only contraception. Availability of safer conception services is still very low in most low income countries. In this study we assessed the knowledge and use of safer conception methods (SCM) among HIV infected women in HIV care in Uganda to inform integration of safer conception in existing FP services.
\end{abstract}

Methods: Data were accrued from a nationally representative cross-sectional survey of 5198 HIV+ women aged 1549 years from 245 HIV clinics in Uganda. Knowledge and use of safer conception methods and associated factors were determined. The measure of association was prevalence ratio (PR) with corresponding $95 \%$ confidence intervals, obtained using a modified Poisson regression via generalized linear models. All the analyses were conducted using STATA version 12.0.

Results: Overall knowledge of any safer conception method was 74.1\% (3852/5198). However only 13.2\% knew 3 to 4 methods, $18.9 \%$ knew only 2 methods and $42 \%$ knew only one method. Knowledge of specific SCM was highest for timed unprotected intercourse (TUI) at 39\% $(n=2027)$ followed by manual self-insemination (MSI) at $34.8 \%(n=1809)$, and pre-exposure prophylaxis (PrEP) at 24.8\% $(n=1289)$. Knowledge of SCM was higher in the Eastern region (84.8\%, $P<0.001)$, among women in HIV-discordant relationships $(76.7 \%, p<0.017)$, and those on ART $(74.5 \%, p<0.034)$. Overall, 1796 (34.6\%) women were pregnant or reported a birth in the past 2 years-overall use of SCM in this group was $11.6 \%$ (209/1796). The odds of use of SCM were significantly lower in Kampala [adj. $P R=0.489(0.314,0.764)]$ or Eastern region $[$ adj.PR $=0.244 ;(0.147,0.405)]$ compared to Northern region. Higher odds of SCM use were associated with HIV status disclosure to partner [adj.PR $=2.613(1.308,5.221)$ ] and sero-discordant compared to HIV+ concordant relationship [adj.PR $=1.637(1.236,2.168)]$. Pre-existing knowledge of any one SCM did not influence SCM use.

Conclusions: Knowledge and use of SCM among HIV+ women in care is low. Efforts to improve HIV status disclosure, integration of safer conception into FP and HIV services and regional efforts to promote sensitization and access to safer conception can help to increase uptake of safer conception methods.

Keywords: Safer conception methods, Knowledge, HIV, Uganda, Reproductive health

\footnotetext{
* Correspondence: vgwokyalya@musph.ac.ug

${ }^{1}$ Makerere University School of Public Health, Kampala, Uganda

Full list of author information is available at the end of the article
}

(c) The Author(s). 2019 Open Access This article is distributed under the terms of the Creative Commons Attribution 4.0 International License (http://creativecommons.org/licenses/by/4.0/), which permits unrestricted use, distribution, and reproduction in any medium, provided you give appropriate credit to the original author(s) and the source, provide a link to the Creative Commons license, and indicate if changes were made. The Creative Commons Public Domain Dedication waiver (http://creativecommons.org/publicdomain/zero/1.0/) applies to the data made available in this article, unless otherwise stated. 


\section{Background}

Uganda has one of the youngest and most rapidly growing populations in the world; its total fertility rate is among the world's highest at 5.8 children per woman [1] yet with a high HIV prevalence of $6.2 \%$ [2]. Between 14 and $73 \%$ of people living with HIV (PLHIV) want to have children [3-5]. About 40\% of HIV-infected women become pregnant post HIV diagnosis $[6,7]$ and over half (57\%) of these pregnancies are planned [6]. In addition approximately half of HIV-affected couples in Uganda are in discordant relationships [8] and a significant proportion $(60 \%)$ of new infections occurs in such relationships [9, 10]. HIV negative partners in serodiscordant relationships in which pregnancy occurs have nearly double the risk of HIV acquisition compared to their counterparts in the absence of pregnancy [11]. Antiretroviral therapy (ART) greatly reduces the transmission risk associated with childbearing, [12] especially when one achieves viral suppression [13] but many PLHIV are either not yet diagnosed or are diagnosed but not yet in care, while some of those on ART may not have achieved viral suppression for various reasons. According to the Global UNAIDS 2017 report, only 60\% of all HIV positive people on treatment in Uganda have achieved viral suppression [13]. Thus, use of safer conception methods (SCM) such as manual self-insemination (MSI), timed unprotected intercourse (TUI) and sperm washing (for those who can afford) remains very relevant in this context to minimize the risk of sexual transmission during attempts to conceive [14].

International reproductive guidelines shifted a decade ago from recommending avoidance of pregnancy to recognizing conception and parenting as realistic options and a fundamental reproductive right for PLHIV and their partners [15]; encouraging detailed pre-conceptual counseling on all their conception options. Since 2001, the US Centers for Disease Control and Prevention (US CDC) has also encouraged information and support for HIV-affected couples who want to explore their reproductive options [16]. The Society of Obstetricians and Gynaecologists of Canada [17] and the South African HIV Clinicians Society [18] provided guidelines for safer conception with a range of strategies. These guidelines include: (i) fostering discussions between the clinicians and the clients on issues of childbearing; (ii) identifying the fertility desires of HIV-infected women and men, with discussions on contraceptive strategies for couples that do not desire a pregnancy; and (iii) management of HIV affected individuals and couples who desire a pregnancy, with emphasis on the management of HIV disease and co-morbidities before attempting conception, and offering specific conception strategies for HIV sero-concordant positive and sero-discordant couples. However, these guidelines have not yet been adopted by governments in resource-limited settings or incorporated as standard of care and as such the use of safer conception methods is still very low in most countries in sub-Saharan Africa and Uganda in particular $[5,19,20]$. Barriers to implementation of these guidelines include patient and provider stigma and lack of patient counseling regarding childbearing, lack of safer conception skills among health providers, and cultural barriers [5, 19].

PLHIV and their providers rarely discuss childbearing prior to pregnancy [21], resulting in a lost opportunity to promote safer conception, as well as contraception. In most sub-Saharan African (SSA) countries [20] including Uganda [5], most PLHIV (60-80\%) do not discuss their fertility intentions with providers; providers have openly discouraged (and even scolded) clients from having children because of transmission and mortality risks [22-25] while clients avoid talking with providers about their pregnancy needs due to perceived provider stigma and internalized stigma. Comprehensive knowledge and counseling about safer conception has remained low, and thus affected the use of safer conception services among HIV-infected clients [20]. A study done among 48 clients attending a specialized HIV care centre in Uganda found that $61 \%$ had heard of one or more methods to reduce risk during conception with knowledge being highest with TUI $(60 \%)$ and least with sperm washing (23\%), but only $37 \%$ $(n=18)$ were able to describe any of the methods [19]. Majority of clients considered safer conception methods as abnormal and expressed concerns such as risk for HIV transmission, which presumably affects the uptake of these methods. Similarly, in a study of SCM in a sample of 400 Ugandan HIV clients in committed heterosexual relationships who have intentions to have a child, just over half knew that MSI (53\%) and TUI (51\%) reduced transmission risk during conception, and 15\% knew of sperm washing and pre-exposure prophylaxis [26]. Only $12 \%$ had used timed unprotected intercourse while trying to conceive, but none had used manual self-insemination or sperm washing [27]. However, most prior studies have been small and the findings may not fully represent the large HIV population in care in Uganda. We therefore assessed knowledge, and correlates of use of SCM in a nationally representative sample of HIV infected women in the five geographical regions of Uganda to inform integration of safer conception into FP and sexual and reproductive health (SRH) services for HIV affected clients.

\section{Methods}

\section{Study design, population and sites}

Data are accrued from a study of $5198 \mathrm{HIV}+$ women from a nationally representative sample of 245 private and public HIV care facilities across five geographical regions in Uganda; Northern, Eastern, Western, Central and Kampala. The purpose of the study was to assess 
sexual and reproductive health (SRH) and family planning (FP) service integration, delivery models, and uptake of HIV care services among HIV-infected individuals in care. The health facilities were selected across various levels of health care delivery in Uganda including hospitals and health centers (HCIV, HCIII, and HCII) with chronic HIV care/treatment clinics. Health centres are lower level service delivery units categorized according to the size of the population served, staffing levels and type of services offered, the lowest being a health centre one (HC I) and the highest a health centre four (HC IV).

\section{Sampling}

A two-stage sampling process was used. In the first stage, a sampling frame with a list of accredited HIV care facilities was used to randomly select an equal number of facilities in each region. The second stage of sampling was selection of study participants at the facility level. All HIV+ women aged 15-49 years who presented at the selected clinics for HIV care on the interview days were registered on their service sign-in daily attendance sheets. Systematic sampling was then conducted to randomly select the required number of eligible women from the daily attendance lists. After sampling, a brief screening tool was used to assess eligibility including age (only those aged 15-49 years were eligible for this study) and being sexually active (only those who had had sexual intercourse at least once within 12 months were eligible). Eligible participants provided written informed consent process before conducting the full interview.

\section{Sample size}

The sample size calculation was based on unmet need for FP as the main outcome of the study assuming a $30 \%$ unmet need for FP among HIV+ women in care, $3.6 \%$ margin of error, $5 \%$ type-I error rate, a design effect of 1.5 and non-response of $10 \%$. Based on these assumptions, we obtained a sample size of 5185 across the five geographical regions (i.e. 1037 respondents per region). Approximately 20 participants were selected from each facility with the exception of the highest volume facilities in Kampala with > 5000 clients in HIV care where 30-50 participants were randomly selected per site. Kampala has fewer but larger volume dedicated HIV facilities compared to the other regions. Overall, participants were selected from 52 facilities in each region except Kampala where participants were drawn from 37 ART accredited facilities.

\section{Data collection methods and procedures}

Using an interviewer-administered structured questionnaire, data were collected on general knowledge about safer conception methods namely; TUI, MSI, PrEP for HIV-uninfected partners, and sperm washing. Women responded to a series of questions on whether or not they knew about SCM, and if they used any of the SCM singly or in combination for those pregnant or reporting childbearing in the past 2 years. Other safer conception questions included questions on strategies to reduce HIV transmission risk when planning for conception; for example, early initiation of ART for HIV-infected individuals, and having an undetectable viral load. Women also responded to questions on reproductive history; children ever been born alive, desire for a (more) child (ren) and timing of the next pregnancy. Data collection was conducted between September and November 2016 by a well-trained and experienced team of 30 interviewers. Pretesting of tools was conducted to check the suitability of various aspects of the questionnaires such as the translation, skip procedures and filtering questions, and modifications were done prior to actual data collection. All data collection tools were translated into the common languages of the selected regions.

\section{Measures}

The primary outcome variable was reported knowledge of safer conception methods, or use of any SCM. Knowledge of safer conception methods was assessed using a series of general awareness and methods-specific statements that were read to the respondents with responses coded as "True", "False" or "Don't Know". General awareness statements sought to explore respondents knowledge on the concept of 'safer conception' in general (e.g. "there are ways that can make conception with an HIV negative partner safer") while methods-specific questions aimed to explore respondents' knowledge of specific SCM (e.g. TUI - "having unprotected sex during the few days each month when the woman is most fertile will help to limit the risk of HIV transmission to an uninfected partner"). Respondents who answered "true" to any of the general or methods-specific statements were presumed to have knowledge of safer conception in general and SCM in particular. Individuals who knew SCM were grouped into those who knew: a) 3-4 methods (designed as having a "high knowledge" of $\mathrm{SCM}$ ); b) only two methods (designated as having "moderate knowledge") or c) only one method (designated as having "poor knowledge"). Use of safer conception methods was determined among women who reported a birth within the last 2 years or were pregnant. A woman was classified as a user of SCM if she reported use of any of the SCM (TUI, MSI, PrEP for the HIV uninfected partner for those who are in sero-discordant relationships, and sperm washing) to reduce the risk of HIV transmission while trying to conceive a child with their partner. 


\section{Data management and analysis}

We conducted descriptive analyses to describe the socio-demographic characteristics of the women in the sample, the HIV diagnosis and treatment status, partner characteristics including their HIV status, knowledge and use of SCM. The associations between knowledge or use of SCM, and woman's characteristics were assessed with prevalence ratio $(\mathrm{PR})$ as the measure of association. PR was obtained using a "modified" Poisson regression model via a generalized linear model with family as Poisson and link as log and robust standard errors. All analysis used Stata version 12. In the bivariate to determine independent factors associated with the outcomes, the models included the following covariates; age, region, religion, health facility level and ownership, education level, wealth quintile, marital status, ART status of client and duration on ART, HIV disclosure status to partner, partner's HIV status, partner's ART status if also HIV positive, and number of biological children. Variables that were significant at a level of $5 \%$ significance or important from other previous studies were included in multivariable analysis.

\section{Results}

\section{Participants' characteristics}

Table 1 shows the characteristics of 5198 women that were considered for this analysis. The mean (SD) age was 32.5 (7.2) years, and $85.6 \%$ were either married $(59.2 \%, n=3079)$ or in a relationship $(26.4 \%, n=1371)$. Enrolment on ART was nearly universal $(96.6 \%, n=$ 5022 ) with a median (IQR) period of $3(2,6)$ years, $57.4 \%(n=2985)$ were in sero-concordant relationships and $18.4 \%(n=954)$ in discordant relationships, the rest did not know their partners' HIV status. Close to a quarter $(23 \%, n=1168)$ of women in this study were either pregnant $(5.6 \%)$ or wanted a child $(17.5 \%)$ and another $28 \%(n=1422)$ did not use a condom on their last sexual encounter because their partner wanted a child. Among those who wanted to conceive, $18 \%(n=122)$ had HIV negative partners. HIV serostatus disclosure to a sexual partner was $84.5 \%(n=4362)$; significantly higher $(p<0.001)$ in HIV sero-concordant $(97.9 \% ; n=2922)$ than in HIV-discordant $(89 \% ; n=849)$ relationships and those with partner of unknown HIV status $(46.9 \%, n=590)$.

\section{Knowledge of safer conception methods and ways to reduce HIV transmission risk}

Overall $80.2 \%(n=4262)$ had general knowledge of safer conception methods and $74.1 \%(n=3852)$ knew at least one SCM. Of those that knew at least one SCM, $42 \%$ ( $n$ $=2183$ ) knew only one method (had low knowledge), $18.9 \%(n=986)$ knew only two methods (had moderate knowledge) and 13.2\% $(n=685)$ knew three to four SCM (had high knowledge). Table 2 shows that knowledge of any one SCM was higher in the Eastern region (84.8\%, $n=877, P<0.001)$, among women in HIV-discordant relationships $(76.7 \%, n=731, p<0.017)$, those in a higher wealth status $(p<0.003)$, and among those on ART $(74.5 \%, n=3741, p<0.034)$. Knowledge of specific SCM was lower for MSI $(35 \%, n=1809)$ compared to TUI $(39.0 \%, n=2027)$, Table 3. TUI knowledge was higher in Central (47\%) and Kampala (46\%) regions while MSI was highest in Eastern region where 63\% of women knew that a man could ejaculate in a condom or container and manually insert the semen into a woman's vagina.

Knowledge about sperm washing was reported by only $18 \%(n=925)$ while only a quarter $(25 \%, n=1289)$ knew of PrEP. Knowledge of SCM varied significantly by geographical regions, significantly higher in the Eastern (adj.PR 1.256, CI: 1.191, 1.324), Kampala (adj.PR 1.138, CI: $1.064,1.218$ ) and central regions (adj.PR 1.136, CI: 1.072, 1.203), Table 4.

\section{Correlates of use of safer conception methods}

Correlates of use of SCM were computed from 1796 women who were either pregnant at the time of the study or reported a birth in the past 2 years. Ever use of any SCM (TUI, MSI, PrEP and sperm washing) was reported by only $11.6 \%$; lowest among those in the Eastern region $(4.6 \%, \mathrm{n}=18)$, Table 5 . Among those who used SCM (11.6\%), majority used TUI (7.2\%), followed by PrEP (4\%). Only 11 women reported that they had ever used MSI $(0.6 \%)$ but no woman reported that they had ever used sperm washing (data not shown).

Table 6 shows that women staying in Kampala (adj.PR 0.489, CI: 0.314, 0.764) and Eastern regions (adj.PR 0.244 , CI: $0.147,0.405)$ were less likely to use safer conception methods while women who disclosed their HIV status to their partners (adj.PR 2.613, CI: 1.308, 5.221) and those in HIV sero-discordant relationships (adj.PR 1.637, CI: 1.236, 2.168) were more likely to use any SCM. Women who were generally aware of SCM were more likely to use the methods (adj.PR 2.953, CI: (1.968, 4.430) but knowledge of specific methods did not influence use of SCM.

\section{Discussion}

In this study of knowledge and use of SCM among HIV-infected women receiving HIV care in Uganda, we found that majority of women had heard about SCM and know at least one method, but knowledge on the specific SCM and the actual use of these methods is very low. Only 35 and 39\% knew MSI and TUI respectively as methods of safer conception and only $18 \%$ knew about sperm washing. SCM methods were ever used by only $11 \%$. These findings show an even lower level of knowledge and use of SCM than what has been shown by other studies $[26,27]$ and imply a very big missed 
Table 1 15-49-year-old HIV positive women in care by selected characteristics

\begin{tabular}{|c|c|c|c|c|c|c|}
\hline \multirow[t]{2}{*}{ Characteristic } & \multirow{2}{*}{$\begin{array}{l}\text { Total, } \\
N=5198 \%\end{array}$} & \multicolumn{5}{|l|}{ Region } \\
\hline & & $\begin{array}{l}\text { Kampala, } \\
N=1048(\%)\end{array}$ & $\begin{array}{l}\text { Central, } \\
N=1032(\%)\end{array}$ & $\begin{array}{l}\text { Eastern, } \\
N=1034(\%)\end{array}$ & $\begin{array}{l}\text { Western, } \\
N=1039 \text { (\%) }\end{array}$ & $\begin{array}{l}\text { Northern, } \\
N=1045 \text { (\%) }\end{array}$ \\
\hline \multicolumn{7}{|l|}{ Age } \\
\hline $15-19$ & $103(2.0)$ & $14(1.3)$ & $22(2.1)$ & $15(1.5)$ & $25(2.4)$ & $27(2.6)$ \\
\hline $200-24$ & $657(12.6)$ & $150(14.3)$ & $132(12.8)$ & $115(11.1)$ & $147(14.1)$ & $113(10.8)$ \\
\hline $25-29$ & $1147(22.1)$ & $273(26.0)$ & $209(20.3)$ & $215(20.8)$ & $238(22.9)$ & $212(20.3)$ \\
\hline $30-39$ & $2254(43.4)$ & $452(43.1)$ & 449 (43.5) & $470(45.5)$ & $437(42.1)$ & $446(42.7)$ \\
\hline $40-49$ & $1037(20.0)$ & $159(15.1)$ & $220(21.3)$ & $219(21.2)$ & $192(18.5)$ & $247(23.6)$ \\
\hline \multicolumn{7}{|l|}{ Health Facility Level ${ }^{a}$} \\
\hline Hospital & $1556(29.9)$ & $224(21.4)$ & $316(30.6)$ & $284(27.5)$ & $343(33.0)$ & $389(37.2)$ \\
\hline $\mathrm{HC} \mathrm{IV}$ & $1540(29.6)$ & $85(8.1)$ & $273(26.5)$ & $405(39.2)$ & $400(38.5)$ & $377(36.1)$ \\
\hline $\mathrm{HC} \| \mathrm{I}$ & $1542(29.7)$ & $417(39.8)$ & $366(35.5)$ & $244(23.6)$ & $256(24.6)$ & $259(24.8)$ \\
\hline $\mathrm{HC} \|$ & $416(8.0)$ & $288(27.5)$ & $1(0.1)$ & $81(7.8)$ & $38(3.7)$ & $8(0.8)$ \\
\hline Private health unit & $112(2.2)$ & $34(3.2)$ & $58(5.6)$ & $20(1.9)$ & $0(0.0)$ & $0(0.0)$ \\
\hline Others & $32(0.6)$ & $0(0.0)$ & $18(1.7)$ & $0(0.0)$ & $2(0.2)$ & $12(1.1)$ \\
\hline \multicolumn{7}{|l|}{ Religion } \\
\hline Catholic & $2136(41.1)$ & 354 (33.8) & $441(42.7)$ & $315(30.5)$ & 415 (39.9) & $611(58.5)$ \\
\hline Anglican / Protestant & $1616(31.1)$ & $284(27.1)$ & $273(26.5)$ & $370(35.8)$ & $410(39.5)$ & $279(26.7)$ \\
\hline Moslem & $663(12.8)$ & $199(19.0)$ & $150(14.5)$ & $183(17.7)$ & $53(5.1)$ & $78(7.5)$ \\
\hline Pentecostal / Born Again / Evangelical & $662(12.7)$ & 188 (17.9) & 137 (13.3) & $155(15)$ & $115(11.1)$ & $67(6.4)$ \\
\hline Others & $121(2.3)$ & $23(2.2)$ & $31(3.0)$ & $11(1.1)$ & $46(4.5)$ & $10(1.0)$ \\
\hline \multicolumn{7}{|l|}{ Marital status } \\
\hline Never married & $107(2.1)$ & $25(2.4)$ & $7(0.7)$ & $23(2.2)$ & $32(3.1)$ & $20(1.9)$ \\
\hline In relationship but not married & $1371(26.4)$ & $349(33.3)$ & $362(35.1)$ & $172(16.6)$ & $163(15.7)$ & $325(31.1)$ \\
\hline Married & $3079(59.2)$ & $596(56.9)$ & $555(53.8)$ & $690(66.7)$ & $672(64.7)$ & $566(54.2)$ \\
\hline Divorced/separated & $412(7.9)$ & $60(5.7)$ & $77(7.5)$ & $85(8.2)$ & $105(10.1)$ & $85(8.1)$ \\
\hline Widowed & $229(4.4)$ & $18(1.7)$ & $31(3)$ & $64(6.2)$ & $67(6.4)$ & $49(4.7)$ \\
\hline \multicolumn{7}{|l|}{ Education $^{\mathrm{b}}$} \\
\hline No education & $726(14.0)$ & $65(6.2)$ & $143(13.9)$ & $145(14.0)$ & $157(15.1)$ & $216(20.7)$ \\
\hline Primary & $2924(56.3)$ & $449(42.8)$ & $606(58.7)$ & $565(54.6)$ & $653(62.8)$ & $651(62.3)$ \\
\hline Secondary & $1381(26.6)$ & $445(42.5)$ & $260(25.2)$ & $303(29.3)$ & $221(21.3)$ & $152(14.5)$ \\
\hline More than secondary & $156(3.0)$ & $89(8.5)$ & $21(2)$ & $21(2.0)$ & $7(0.7)$ & $18(1.7)$ \\
\hline Missing & $11(0.2)$ & $0(0.0)$ & $2(0.2)$ & $0(0.0)$ & $1(0.1)$ & $8(0.8)$ \\
\hline \multicolumn{7}{|l|}{ Wealth quintile } \\
\hline Lowest & $1054(20.3)$ & $22(2.1)$ & $170(16.5)$ & $282(27.3)$ & $230(22.1)$ & $350(33.5)$ \\
\hline Second & $1026(19.7)$ & $35(3.3)$ & $221(21.4)$ & $244(23.6)$ & $224(21.6)$ & $302(28.9)$ \\
\hline Middle & $1041(20.0)$ & $64(6.1)$ & $231(22.4)$ & $253(24.5)$ & $249(24.0)$ & $244(23.3)$ \\
\hline Fourth & $1039(20.0)$ & $328(31.3)$ & $228(22.1)$ & $146(14.1)$ & $239(23.0)$ & $98(9.4)$ \\
\hline Highest' & $1038(20.0)$ & $599(57.2)$ & $182(17.6)$ & $109(10.5)$ & $97(9.3)$ & $51(4.9)$ \\
\hline \multicolumn{7}{|l|}{ Owns a radio } \\
\hline No & $1822(35.1)$ & $346(33.0)$ & $294(28.5)$ & 399 (38.6) & $354(34.1)$ & $429(41.1)$ \\
\hline Yes & $3376(64.9)$ & $702(67.0)$ & 738 (71.5) & $635(61.4)$ & $685(65.9)$ & $616(58.9)$ \\
\hline \multicolumn{7}{|l|}{ Owns a Cell phone } \\
\hline No & 991 (19.1) & $58(5.5)$ & $187(18.1)$ & $240(23.2)$ & $243(23.4)$ & $263(25.2)$ \\
\hline
\end{tabular}


Table 1 15-49-year-old HIV positive women in care by selected characteristics (Continued)

\begin{tabular}{|c|c|c|c|c|c|c|}
\hline \multirow[t]{2}{*}{ Characteristic } & \multirow{2}{*}{$\begin{array}{l}\text { Total, } \\
N=5198 \%\end{array}$} & \multicolumn{5}{|l|}{ Region } \\
\hline & & $\begin{array}{l}\text { Kampala, } \\
N=1048(\%)\end{array}$ & $\begin{array}{l}\text { Central, } \\
N=1032(\%)\end{array}$ & $\begin{array}{l}\text { Eastern, } \\
N=1034 \text { (\%) }\end{array}$ & $\begin{array}{l}\text { Western, } \\
N=1039 \text { (\%) }\end{array}$ & $\begin{array}{l}\text { Northern, } \\
N=1045(\%)\end{array}$ \\
\hline Yes & $4207(80.9)$ & $990(94.5)$ & $845(81.9)$ & $794(76.8)$ & $796(76.6)$ & $782(74.8)$ \\
\hline \multicolumn{7}{|c|}{ On antiretroviral therapy } \\
\hline No & $176(3.4)$ & $51(4.9)$ & $6(0.6)$ & $26(2.5)$ & $52(5.0)$ & $41(3.9)$ \\
\hline Yes & 5022 (96.6) & $997(95.1)$ & $1026(99.4)$ & $1008(97.5)$ & $987(95.0)$ & $1004(96.1)$ \\
\hline \multicolumn{7}{|c|}{ Duration on ART (Years) } \\
\hline$<1$ & $562(11.3)$ & $166(16.8)$ & $128(12.5)$ & $87(8.7)$ & $100(10.2)$ & $81(8.1)$ \\
\hline 1 & $570(11.4)$ & $127(12.8)$ & $129(12.6)$ & $105(10.5)$ & $110(11.2)$ & $99(9.9)$ \\
\hline 2 & $739(14.8)$ & $140(14.1)$ & $157(15.4)$ & $138(13.8)$ & $154(15.7)$ & $150(15.1)$ \\
\hline $3+$ & $3118(62.5)$ & $558(56.3)$ & $607(59.5)$ & $670(67)$ & $617(62.9)$ & $666(66.9)$ \\
\hline \multicolumn{7}{|c|}{ Partner's HIV Status } \\
\hline Positive & $2985(57.4)$ & $468(44.7)$ & $539(52.2)$ & $593(57.4)$ & $585(56.3)$ & $800(76.6)$ \\
\hline Negative & $954(18.4)$ & $243(23.2)$ & $178(17.3)$ & $201(19.4)$ & $213(20.5)$ & $119(11.4)$ \\
\hline Don't know & $1259(24.2)$ & $337(32.2)$ & $315(30.5)$ & $240(23.2)$ & $241(23.2)$ & $126(12.1)$ \\
\hline \multicolumn{7}{|c|}{ Disclosed HIV status to partner } \\
\hline No & $800(15.5)$ & $301(29.0)$ & $214(20.8)$ & $114(11.1)$ & $133(12.9)$ & $38(3.7)$ \\
\hline Yes & $4362(84.5)$ & $736(71.0)$ & $813(79.2)$ & $914(88.9)$ & $902(87.1)$ & $997(96.3)$ \\
\hline \multicolumn{7}{|c|}{ Number of biological children } \\
\hline 0 & $1342(25.8)$ & $267(25.5)$ & $318(30.8)$ & $207(20.0)$ & $330(31.8)$ & $220(21.1)$ \\
\hline 1 & $588(11.3)$ & $193(18.4)$ & $104(10.1)$ & $93(9.0)$ & $104(10.0)$ & $94(9.0)$ \\
\hline 2 & $852(16.4)$ & $220(21.0)$ & $164(15.9)$ & $133(12.9)$ & $176(16.9)$ & $159(15.2)$ \\
\hline 3 & $764(14.7)$ & $169(16.1)$ & $132(12.8)$ & $157(15.2)$ & $147(14.1)$ & $159(15.2)$ \\
\hline $4+$ & $1652(31.8)$ & 199 (19.0) & $314(30.4)$ & $444(42.9)$ & $282(27.1)$ & $413(39.5)$ \\
\hline
\end{tabular}

aHealth facility level refers to the categorization of levels of health care according to the size of the population served, the staffing and type of services offered, HC II serves up to 5000 people and only offering out-patient services to hospital that offers specialized care in addition to in and out-patient services and surgical operations.

${ }^{b}$ Education categories refer to the highest level of education attended, whether or not that level was completed.

opportunity for preventing HIV transmission from such a large sexually active HIV positive population (women who had had sex within 12 months).

Our data shows that general knowledge of safer conception increased the likelihood of using the methods (i.e. SCM use was twice as high in those who had general knowledge about safer conception than in those who were not) but knowledge of specific methods did not seem to influence use. This is contrary to what has been documented from prior studies [27] which show that high knowledge is related to increased use of the SCM. The difference in findings may be due to the limited availability of the service although we did not have data to establish service availability. Previous research has shown that safer conception services such as sperm washing remain primarily limited to specialist sites, even in high-income countries $[28,29]$ and this limits use of the services. The region that had the highest knowledge of SCM mainly knew MSI which has been shown to be among the least used methods [27]. It is also possible that the relatively high knowledge among respondents in some of the regions was due to the effect of pilot safer conception studies that were conducted in TASO Jinja (a big HIV care centre in the Eastern region) and TASO Kampala (a big HIV care centre in Kampala region) that tested the feasibility and acceptability of safer conception counseling among HIV positive clients [19, 26, 27]. However, TASO did not provide a comprehensive service package that could greatly influence use. Indeed, our findings show that even in Kampala and Jinja regions where the pilot studies were conducted, use of SCM remained low, suggesting that while these pilot studies could have succeeded in raising awareness about SCM, they did not influence its use, probably due to lack of access.

Earlier studies done in selected health facilities in Uganda [5, 30], South Africa [20, 23] and Mozambique [22] also revealed that several clients had heard about some of the SCM (especially TUI), but could not provide a comprehensive description of how they are implemented 
Table 2 Knowledge of at least one method of Safer Conception by selected characteristics

Among all women age 15-49, in HIV care, the percentage who answered 'true' to at least one knowledge statement on safer conception strategies, by background characteristics

\begin{tabular}{|c|c|c|c|c|}
\hline & $\%$ Not Knowledgeable & \% Knowledgeable & Number & $P$-Value \\
\hline \multicolumn{5}{|l|}{ Age } \\
\hline $15-19$ & 39.8 & 60.2 & 103 & \multirow[t]{5}{*}{0.014} \\
\hline $20-24$ & 27.4 & 72.6 & 657 & \\
\hline $25-29$ & 24.5 & 75.5 & 1147 & \\
\hline $30-39$ & 25.6 & 74.4 & 2254 & \\
\hline $40-49$ & 25.7 & 74.3 & 1037 & \\
\hline \multicolumn{5}{|l|}{ Region } \\
\hline Kampala & 23.0 & 77.0 & 1048 & \multirow[t]{5}{*}{$<0.001$} \\
\hline Central & 22.7 & 77.3 & 1032 & \\
\hline Eastern & 15.2 & 84.8 & 1034 & \\
\hline Western & 34.9 & 65.1 & 1039 & \\
\hline Northern & 33.4 & 66.6 & 1045 & \\
\hline \multicolumn{5}{|l|}{ Religion } \\
\hline Catholic & 27.4 & 72.6 & 2136 & \multirow[t]{6}{*}{0.153} \\
\hline Anglican/Protestant & 25.6 & 74.4 & 1616 & \\
\hline Moslem & 22.0 & 78.0 & 663 & \\
\hline Pentecostal/Born again/Evangelic & 25.4 & 74.6 & 662 & \\
\hline $\mathrm{SDA}^{\mathrm{a}}$ & 26.0 & 74.0 & 104 & \\
\hline Other & 23.5 & 76.5 & 17 & \\
\hline \multicolumn{5}{|l|}{ On ART } \\
\hline No & 32.9 & 67.1 & 161 & \multirow[t]{2}{*}{0.034} \\
\hline Yes & 25.5 & 74.5 & 5022 & \\
\hline \multicolumn{5}{|l|}{ Duration on ART (Years) } \\
\hline$<1$ & 27.7 & 72.3 & 559 & \multirow[t]{4}{*}{0.401} \\
\hline 1 & 26.3 & 73.7 & 570 & \\
\hline 2 & 26.3 & 73.7 & 739 & \\
\hline 3 & 24.7 & 75.3 & 3118 & \\
\hline \multicolumn{5}{|l|}{ Currently Married } \\
\hline No & 26.9 & 73.1 & 2119 & \multirow[t]{2}{*}{0.136} \\
\hline Yes & 25.1 & 74.9 & 3079 & \\
\hline \multicolumn{5}{|l|}{ Marital status } \\
\hline Never married & 28.0 & 72.0 & 107 & \multirow[t]{5}{*}{0.572} \\
\hline In relationship but not married & 26.5 & 73.5 & 1371 & \\
\hline Married & 25.1 & 74.9 & 3079 & \\
\hline Divorced/Separated & 28.4 & 71.6 & 412 & \\
\hline Widowed & 26.2 & 73.8 & 229 & \\
\hline \multicolumn{5}{|l|}{ HIV Disclosure to Partner } \\
\hline No & 26.5 & 73.5 & 800 & \multirow[t]{2}{*}{0.634} \\
\hline Yes & 25.7 & 74.3 & 4362 & \\
\hline \multicolumn{5}{|l|}{ HIV Status of Partner } \\
\hline Positive & 25.6 & 74.4 & 2985 & \multirow[t]{2}{*}{0.017} \\
\hline Negative & 23.3 & 76.7 & 954 & \\
\hline
\end{tabular}


Table 2 Knowledge of at least one method of Safer Conception by selected characteristics (Continued)

Among all women age 15-49, in HIV care, the percentage who answered 'true' to at least one knowledge statement on safer conception strategies, by background characteristics

\begin{tabular}{|c|c|c|c|c|}
\hline & $\%$ Not Knowledgeable & \% Knowledgeable & Number & $P$-Value \\
\hline DKDR & 28.5 & 71.5 & 1259 & \\
\hline \multicolumn{5}{|l|}{ Education } \\
\hline No education & 27.4 & 72.6 & 726 & \multirow[t]{5}{*}{0.574} \\
\hline Primary & 26.1 & 73.9 & 2924 & \\
\hline Secondary & 25.0 & 75.0 & 1381 & \\
\hline More than secondary & 21.8 & 78.2 & 156 & \\
\hline Missing & 27.3 & 72.7 & 11 & \\
\hline \multicolumn{5}{|l|}{ Wealth Quintile } \\
\hline Lowest & 28.9 & 71.1 & 1054 & \multirow[t]{5}{*}{0.003} \\
\hline Second & 28.6 & 71.4 & 1026 & \\
\hline Middle & 25.1 & 74.9 & 1041 & \\
\hline Fourth & 23.3 & 76.7 & 1039 & \\
\hline Highest & 23.4 & 76.6 & 1038 & \\
\hline \multicolumn{5}{|l|}{ Level Health Facility } \\
\hline Hospital & 26.5 & 73.5 & 1556 & \multirow[t]{6}{*}{0.008} \\
\hline Health Center IV & 26.5 & 73.5 & 1540 & \\
\hline Health Center III & 26.2 & 73.8 & 1542 & \\
\hline Health Center II & 23.6 & 76.4 & 416 & \\
\hline Private Health Unit & 10.7 & 89.3 & 112 & \\
\hline Others & 30.8 & 69.2 & 26 & \\
\hline \multicolumn{5}{|l|}{ Ownership } \\
\hline Government/Public & 26.1 & 73.9 & 3575 & \multirow[t]{4}{*}{0.784} \\
\hline Mission/NGO/Private not for prof & 25.3 & 74.7 & 1549 & \\
\hline Private for profit & 23.9 & 76.1 & 71 & \\
\hline Total & 25.9 & 74.1 & 5198 & \\
\hline
\end{tabular}

${ }^{\mathrm{a}} \mathrm{SDA}$ refers to people of the Seventh Day Adventist Faith

and the clients who reported using methods exhibited partial understanding. Clients with knowledge about safer conception are more likely to open up and initiate child bearing discussions with providers and thus use the service, but need informed providers who will feel more confident talking about issues of conception with HIV positive clients [20]. Knowledge gap among health workers is one of the major reasons why PLHIV do not discuss their fertility desires with providers and hence do not utilize safer conception services $[19,27,30]$. This calls for efforts to improve client and provider education and sensitization about safer conception, while also exploiting the wide coverage of phones and radios that was shown by results of this paper. Addressing this gap will enable effective integration of safer conception into routine family planning services as well as HIV care services.

Higher knowledge and use of SCM was significantly associated with being in an HIV sero-discordant relationship. Discordance is often associated with a dilemma of safer sex practices [7] because of the fear of transmitting HIV infection to partner and child, and this dilemma is likely to yield a search for information on safer conception options and a desire to use them. The increased likelihood of use of SCM among women in HIV sero-discordant relationships is an indication that strengthening safer conception programs with increased focus on clients in HIV sero-discordant relationships may greatly reduce HIV transmission. Increased focus on discordant couples has been shown to increase use of SCM [30]. The fact that $18 \%$ of clients who wanted a child or did not use a condom because their partner wanted a child had HIV negative partners further demonstrates a missed opportunity to intercept HIV transmission among these clients, a gap that could be filled if safer conception services were readily available and more clients fully sensitized about them. 
Table 3 Knowledge of specific safer conception methods

Among all women age 15-49, in HIV care, the percentage who answered 'true' to knowledge statements on specific safer conception strategies, by background characteristics

\begin{tabular}{|c|c|c|c|c|c|c|}
\hline \multirow{2}{*}{$\begin{array}{l}\text { Background } \\
\text { characteristic }\end{array}$} & \multicolumn{5}{|c|}{ Women knowledgeable that: } & \multirow{2}{*}{$\begin{array}{l}\text { Number o } \\
\text { women }\end{array}$} \\
\hline & $\begin{array}{l}\text { Having an } \\
\text { "undetectable" } \\
\text { amount of HIV } \\
\text { Virus reduces } \\
\text { risk of HIV } \\
\text { transmission }\end{array}$ & $\begin{array}{l}\text { Having the man ejaculate } \\
\text { into a condom or } \\
\text { container and then } \\
\text { manually inject the semen } \\
\text { into the woman's vagina } \\
\text { is a way to reduce risk of } \\
\text { HIV transmission if the } \\
\text { man is HIV negative (MSI) }\end{array}$ & $\begin{array}{l}\text { Having unprotected sex } \\
\text { during the few days each } \\
\text { month when the woman } \\
\text { is most fertile will help to } \\
\text { limit the risk of HIV } \\
\text { transmission to an } \\
\text { uninfected partner (TUI) }\end{array}$ & $\begin{array}{l}\text { There is } \\
\text { technology } \\
\text { available that can } \\
\text { cleanse a man's } \\
\text { sperm or semen of } \\
\text { the HIV virus } \\
\text { (Sperm washing) }\end{array}$ & $\begin{array}{l}\text { HIV medications can be } \\
\text { taken by an HIV-negative } \\
\text { (or unknown status) part- } \\
\text { ner that will reduce their } \\
\text { risk of getting infected by } \\
\text { their HIV+ partner (PrEP) }\end{array}$ & \\
\hline \multicolumn{7}{|l|}{ Age } \\
\hline $15-19$ & 26.7 & 24.8 & 31 & 16.8 & 27.6 & 103 \\
\hline $20-24$ & 32.2 & 34.2 & 37.5 & 16.3 & 22.5 & 657 \\
\hline $25-29$ & 35.1 & 36.4 & 40.1 & 15.6 & 26.4 & 1147 \\
\hline $30-39$ & 34.3 & 35.7 & 39.7 & 19 & 24.4 & 2254 \\
\hline $40-49$ & 33.2 & 32.6 & 38.1 & 18.8 & 25.1 & 1037 \\
\hline \multicolumn{7}{|l|}{ Marital status } \\
\hline $\begin{array}{l}\text { Never } \\
\text { married }\end{array}$ & 34.9 & 37.7 & 32.1 & 18.9 & 29.5 & 107 \\
\hline $\begin{array}{l}\text { In } \\
\text { relationship } \\
\text { but not } \\
\text { married }\end{array}$ & 36.7 & 32.9 & 38.1 & 17.3 & 23.2 & 1371 \\
\hline Married & 33.6 & 35.3 & 39.9 & 18 & 25.2 & 3079 \\
\hline $\begin{array}{l}\text { Divorced/ } \\
\text { separated }\end{array}$ & 29.5 & 35.5 & 38.8 & 19.1 & 26.8 & 412 \\
\hline Widowed & 26.9 & 36.8 & 36.4 & 16.3 & 23.5 & 229 \\
\hline \multicolumn{7}{|l|}{ Region } \\
\hline Kampala & 41.4 & 25.3 & 45.6 & 19.6 & 25.8 & 1048 \\
\hline Central & 43.3 & 30.8 & 46.9 & 18.4 & 17.4 & 1032 \\
\hline Eastern & 33 & 62.5 & 38 & 29.2 & 37 & 1034 \\
\hline Western & 21.9 & 30.4 & 33.3 & 7.2 & 18.9 & 1039 \\
\hline Northern & 29.6 & 25.2 & 31.4 & 14.8 & 24.8 & 1045 \\
\hline \multicolumn{7}{|l|}{ Education } \\
\hline $\begin{array}{l}\text { No } \\
\text { education }\end{array}$ & 30.5 & 31.5 & 40.4 & 18.9 & 23.1 & 726 \\
\hline Primary & 33.5 & 34.5 & 39.9 & 17.6 & 24.1 & 2924 \\
\hline Secondary & 35.5 & 37.2 & 36.9 & 17.7 & 26.9 & 1381 \\
\hline $\begin{array}{l}\text { More than } \\
\text { secondary }\end{array}$ & 39.7 & 36.5 & 36.5 & 19.9 & 27.1 & 156 \\
\hline Missing & 63.6 & 18.2 & 18.2 & 9.1 & 36.4 & 11 \\
\hline \multicolumn{7}{|l|}{ Wealth quintile } \\
\hline Lowest & 30.3 & 34.8 & 33.3 & 16 & 24.1 & 1054 \\
\hline Second & 32.5 & 34.9 & 37.2 & 17.1 & 23.6 & 1026 \\
\hline Middle & 33.9 & 37.2 & 41.3 & 18.5 & 25.7 & 1041 \\
\hline Fourth & 35.4 & 34.7 & 41.6 & 18.3 & 25.1 & 1039 \\
\hline Highest & 37.2 & 32.4 & 41.7 & 19.3 & 25.5 & 1038 \\
\hline Total & 33.8 & 34.8 & 39.0 & 17.8 & 24.8 & 5198 \\
\hline
\end{tabular}


Table 4 Correlates of knowledge of safer conception methods Distribution of women, in HIV care, aged 15-49 who reported that they knew any safer conception method (TUI, MSI, PrEP) by selected background characteristics

\begin{tabular}{|c|c|c|c|c|}
\hline \multirow{2}{*}{$\begin{array}{l}\text { Background } \\
\text { characteristic }\end{array}$} & \multicolumn{2}{|l|}{ Bivariate } & \multicolumn{2}{|l|}{ Multivariate } \\
\hline & PR(95\% Cl) & $p$-value & PR(95\% Cl) & $p$-value \\
\hline \multicolumn{5}{|l|}{ Age } \\
\hline $15-19$ & Ref & & & \\
\hline $20-24$ & $\begin{array}{l}1.206 \\
(1.024,1.421)\end{array}$ & 0.025 & $\begin{array}{l}1.150 \\
(0.977,1.354)\end{array}$ & 0.093 \\
\hline $25-29$ & $\begin{array}{l}1.254 \\
(1.068,1.473)\end{array}$ & 0.006 & $\begin{array}{l}1.188 \\
(1.011,1.395)\end{array}$ & 0.036 \\
\hline $30-39$ & $\begin{array}{l}1.237 \\
(1.055,1.449)\end{array}$ & 0.009 & $\begin{array}{l}1.168(0.996, \\
1.371)\end{array}$ & 0.056 \\
\hline $40-49$ & $\begin{array}{l}1.235 \\
(1.051,1.451)\end{array}$ & 0.010 & $\begin{array}{l}1.165 \\
(0.990,1.371)\end{array}$ & \\
\hline
\end{tabular}

Region

$\begin{array}{lllll}\text { Northern } & \text { Ref } & & & \\ \text { Kampala } & 1.156 & 0.000 & 1.138 & 0.000 \\ & (1.095,1.220) & & (1.064,1.218) & \\ \text { Central } & 1.161 & 0.000 & 1.136 & 0.000 \\ & (1.099,1.226) & & (1.072,1.203) & \\ \text { Eastern } & 1.273 & 0.000 & 1.256 & 0.000 \\ & (1.211,1.339) & & (1.191,1.324) & \\ \text { Western } & 0.977 & 0.459 & 0.956 & 0.172 \\ & (0.918,1.039) & & (0.896,1.019) & \end{array}$

Religion

$\begin{array}{lllll}\text { Catholic } & \text { Ref } & & & \\ \text { Anglican/Protestant } & 1.027 & 0.196 & 1.011 & 0.583 \\ & (0.987,1.066) & & (0.972,1.051) & \\ \text { Moslem } & 1.074 & 0.003 & 1.016 & 0.526 \\ & (1.024,1.127) & & (0.967,1.067) & \\ \text { Pentecostal/Born } & 1.028 & 0.288 & 0.994 & 0.834 \\ \text { again/Evangelic } & (0.977,1.083) & & (0.944,1.047) & \\ \text { SDA } & 1.020 & 0.736 & 1.034 & 0.576 \\ & (0.908,1.147) & & (0.919,1.162) & \\ \text { Other } & 1.054 & 0.698 & 1.108 & 0.482 \\ & (0.808,1.373) & & (0.832,1.474) & \end{array}$

On ART

$\begin{array}{ll}\text { No } & \text { Ref } \\ \text { Yes } & 1.110(0.995, \quad 0.061 \\ & 1.239)\end{array}$

Duration on ART (Years)

$\begin{array}{lll}<1 & \text { Ref } & \\ 1 & 1.019 & 0.593 \\ & (0.949,1.094) & \\ 2 & 1.020 & 0.554 \\ & (0.954,1.091) & \\ 3 & 1.042 & 0.144 \\ & (0.986,1.101) & \end{array}$

Currently Married

$\begin{array}{lll}\text { No } & \text { Ref } & \\ \text { Yes } & 1.025 & 0.139\end{array}$

Table 4 Correlates of knowledge of safer conception methods (Continued)

Distribution of women, in HIV care, aged 15-49 who reported that they knew any safer conception method (TUI, MSI, PrEP) by selected background characteristics

\begin{tabular}{|c|c|c|c|c|}
\hline \multirow{2}{*}{$\begin{array}{l}\text { Background } \\
\text { characteristic }\end{array}$} & \multicolumn{2}{|l|}{ Bivariate } & \multicolumn{2}{|l|}{ Multivariate } \\
\hline & $\mathrm{PR}(95 \% \mathrm{Cl})$ & $p$-value & $\mathrm{PR}(95 \% \mathrm{Cl})$ & $p$-value \\
\hline & $(0.992,1.059)$ & & & \\
\hline \multicolumn{5}{|l|}{ Marital status } \\
\hline Never married & Ref & & & \\
\hline $\begin{array}{l}\text { In relationship but not } \\
\text { married }\end{array}$ & $\begin{array}{l}1.021 \\
(0.903,1.154)\end{array}$ & 0.743 & & \\
\hline Married & $\begin{array}{l}1.041 \\
(0.923,1.173)\end{array}$ & 0.514 & & \\
\hline Divorced/Separated & $\begin{array}{l}0.995 \\
(0.871,1.136)\end{array}$ & 0.941 & & \\
\hline Widowed & $\begin{array}{l}1.025 \\
(0.890,1.181)\end{array}$ & 0.727 & & \\
\hline \multicolumn{5}{|l|}{ HIV Disclosure to Partner } \\
\hline No & Ref & & & \\
\hline Yes & $\begin{array}{l}1.011 \\
(0.966,1.057)\end{array}$ & 0.638 & & \\
\hline \multicolumn{5}{|l|}{ HIV Status of Partner } \\
\hline Positive & Ref & & & \\
\hline Negative & $\begin{array}{l}1.031 \\
(0.989,1.074)\end{array}$ & 0.145 & $\begin{array}{l}1.018 \\
(0.977,1.061)\end{array}$ & 0.395 \\
\hline DK/DR & $\begin{array}{l}0.960 \\
(0.922,1.000)\end{array}$ & 0.051 & $\begin{array}{l}0.957 \\
(0.911,1.006)\end{array}$ & 0.083 \\
\hline
\end{tabular}

Education

$\begin{array}{lll}\text { No education } & \text { Ref } & \\ \text { Primary } & 1.018 & 0.478 \\ & (0.969,1.069) & \\ \text { Secondary } & 1.033 & 0.233 \\ & (0.979,1.091) & \\ \text { More than secondary } & 1.077 & 0.121 \\ & (0.980,1.184) & \\ \text { Missing } & 1.002 & 0.992 \\ & (0.696,1.443) & \end{array}$

Wealth Quintiles

$\begin{array}{lllll}\text { Lowest } & \text { Ref } & & & \\ \text { Second } & 1.005 & 0.848 & 1.016 & 0.578 \\ & (0.952,1.062) & & (0.961,1.073) & \\ \text { Middle } & 1.054 & 0.047 & 1.062 & 0.027 \\ & (1.001,1.111) & & (1.007,1.119) & \\ \text { Fourth } & 1.079 & 0.003 & 1.089 & 0.003 \\ & (1.026,1.136) & & (1.031,1.152) & \\ \text { Highest } & 1.078 & 0.004 & 1.055 & 0.090 \\ & (1.024,1.134) & & (0.992,1.122) & \end{array}$

Level Health Facility

$\begin{array}{lllll}\text { Hospital } & \text { Ref } & & & \\ \text { Health Center IV } & 1.001 & 0.975 & 1.002 & 0.939 \\ & (0.959,1.044) & & (0.958,1.048) & \\ \text { Health Center III } & 1.005 & 0.829 & 0.994 & 0.801\end{array}$


Table 4 Correlates of knowledge of safer conception methods (Continued)

\begin{tabular}{|c|c|c|c|c|}
\hline \multirow{2}{*}{$\begin{array}{l}\text { Background } \\
\text { characteristic }\end{array}$} & \multicolumn{2}{|l|}{ Bivariate } & \multicolumn{2}{|l|}{ Multivariate } \\
\hline & $\mathrm{PR}(95 \% \mathrm{Cl})$ & $p$-value & $\mathrm{PR}(95 \% \mathrm{Cl})$ & $p$-value \\
\hline & $(0.963,1.048)$ & & $(0.952,1.039)$ & \\
\hline Health Center II & $\begin{array}{l}1.041 \\
(0.979,1.106)\end{array}$ & 0.202 & $\begin{array}{l}0.962 \\
(0.898,1.031)\end{array}$ & 0.270 \\
\hline Private Health Unit & $\begin{array}{l}1.215 \\
(1.132,1.305)\end{array}$ & 0.000 & $\begin{array}{l}1.142 \\
(1.058,1.234)\end{array}$ & 0.001 \\
\hline Others & $\begin{array}{l}0.942 \\
(0.728,1.219)\end{array}$ & 0.653 & $\begin{array}{l}0.966 \\
(0.748,1.248)\end{array}$ & 0.790 \\
\hline \multicolumn{5}{|l|}{ Ownership } \\
\hline Government/Public & Ref & & & \\
\hline $\begin{array}{l}\text { Mission/NGO/Private } \\
\text { not for profit }\end{array}$ & $\begin{array}{l}1.011 \\
(0.976,1.047)\end{array}$ & 0.550 & & \\
\hline Private for profit & $\begin{array}{l}1.029 \\
(0.902,1.174)\end{array}$ & 0.670 & & \\
\hline
\end{tabular}

Use of SCM was also associated with disclosure of HIV sero-status to one's sexual partner. Disclosure of HIV status to one's partner increases partner communication and negotiation on sexual and reproductive health goals and would thus increase chances of using SCM which requires the cooperation of the sexual partner. Involvement of a partner in safer conception counseling ensures that both the man and woman are informed and motivated to accurately employ the appropriate safer conception method [26]. It's thus important that efforts to increase uptake for safer conception promote disclosure of HIV status and partner involvement. The generally high (83.9\%) rate of disclosure among the study population presents an opportunity to introduce safer conception services to as many clients as are in need while aiming to support those that have not disclosed with assisted disclosure services.

Increased knowledge was also associated with being on ART although this did not necessarily influence SCM use. As clients become more stable and healthier on ART, they start to see possibilities of fulfilling their reproductive health needs and probably inquiring about possible alternatives. It is also likely that those who are on ART have stayed in care longer with better adjustment to reproductive health challenges and increased chances of knowing about safer conception options. The limited use of SCM in this group may be explained by the limited availability of the service but also the increasing sensitization in HIV care centres about the need to achieve viral suppression in limiting sexual transmission as well as the increased availability of viral load testing. Clients may find it sufficient to rely on the viral suppression as a strategy to achieve their reproductive desires
Table 5 Use of safer conception methods

\begin{tabular}{|c|c|c|}
\hline \multicolumn{3}{|c|}{$\begin{array}{l}\text { Percent distribution of women, in HIV care, aged } 15-49 \text { who report that } \\
\text { they have ever used any safer conception method (TUI, MSI and PrEP) to } \\
\text { reduce HIV transmission by selected background characteristics }\end{array}$} \\
\hline Background characteristic & Percent, \% & Number of women \\
\hline \multicolumn{3}{|l|}{ Age } \\
\hline $15-19$ & 14.0 & 43 \\
\hline $20-24$ & 12.4 & 355 \\
\hline $25-29$ & 11.5 & 529 \\
\hline $30-39$ & 23.6 & 744 \\
\hline $40-49$ & 19.5 & 125 \\
\hline \multicolumn{3}{|l|}{ Region } \\
\hline Kampala & 8.2 & 355 \\
\hline Central & 13.8 & 290 \\
\hline Eastern & 4.6 & 395 \\
\hline Western & 13.7 & 424 \\
\hline Northern & 19.3 & 332 \\
\hline \multicolumn{3}{|l|}{ Religion } \\
\hline Catholic & 11.2 & 723 \\
\hline Anglican / Protestant & 14.1 & 560 \\
\hline Moslem & 9.0 & 256 \\
\hline Pentecostal / Born Again / Evangelical & 11.2 & 215 \\
\hline Others & 19.5 & 42 \\
\hline \multicolumn{3}{|l|}{ Marital status } \\
\hline Never married & 5.0 & 20 \\
\hline In relationship but not married & 10.6 & 396 \\
\hline Married & 12.2 & 1246 \\
\hline Divorced/separated & 12.1 & 99 \\
\hline Widowed & 5.7 & 35 \\
\hline \multicolumn{3}{|l|}{ Education } \\
\hline No education & 11.6 & 224 \\
\hline Primary & 12.3 & 1028 \\
\hline Secondary & 10.2 & 491 \\
\hline More than secondary & 14.0 & 50 \\
\hline Missing & 0.0 & 3 \\
\hline \multicolumn{3}{|l|}{ General awareness of Safer Conception } \\
\hline No & 7.0 & 371 \\
\hline Yes & 12.9 & 1425 \\
\hline
\end{tabular}

Knowledge of any one Safer Conception method

$\begin{array}{lll}\text { No } & 11.8 & 601 \\ \text { Yes } & 11.5 & 1195\end{array}$

Knowledge Categories of Safer Conception

$\begin{array}{lcc}\begin{array}{l}\text { Knew only one method (low } \\ \text { knowledge) }\end{array} & 11.8 & 1394 \\ \begin{array}{l}\text { Knew two methods (moderate } \\ \text { knowledge) }\end{array} & 13.2 & 243 \\ \text { Knew 3-4 methods (high knowledge) } & 8.6 & 159\end{array}$

Total $15-49$

$11.6 \quad 1796$ 
Table 6 Correlates of use of safer conception methods

Distribution of women, in HIV care, aged 15-49 who report that they have ever used any safer conception methods (TUI, MSI, PrEP) to reduce HIV transmission by selected background characteristics

\begin{tabular}{|c|c|c|c|c|}
\hline \multirow{2}{*}{$\begin{array}{l}\text { Background } \\
\text { characteristic }\end{array}$} & \multicolumn{2}{|l|}{ Bivariate } & \multicolumn{2}{|l|}{ Multivariate } \\
\hline & $\overline{P R(95 \% ~ C l)}$ & $\overline{p \text {-value }}$ & $\overline{P R(95 \% ~ C l)}$ & $p$-value \\
\hline \multicolumn{5}{|l|}{ Age } \\
\hline $15-19$ & Ref & & & \\
\hline $20-24$ & $0.888(0.402,1.961)$ & 0.769 & & \\
\hline $25-29$ & $0.826(0.379,1.801)$ & 0.631 & & \\
\hline $30-39$ & $0.809(0.375,1.746)$ & 0.589 & & \\
\hline $40-49$ & $0.803(0.329,1.958)$ & 0.629 & & \\
\hline
\end{tabular}

Region

$\begin{array}{lllll}\text { Northern } & \text { Ref } & & \text { Ref } & \\ \text { Kampala } & 0.424(0.281,0.640) & 0.001 & 0.489 & 0.002 \\ & & & (0.314,0.764) & \\ \text { Central } & 0.716(0.498,1.028) & 0.070 & 0.818 & 0.282 \\ & & & (0.567,1.179) & \\ \text { Eastern } & 0.236(0.143,0.391) & 0.001 & 0.244 & 0.001 \\ & & & (0.147,0.405) & \\ \text { Western } & 0.709(0.513,0.982) & 0.039 & 0.726 & 0.063 \\ & & & (0.518,1.017) & \end{array}$

Health Facility Level

Hospital Ref Ref

Health Center IV $1.076(0.769,1.506) \quad 0.667 \quad 1.159 \quad 0.390$

Health Center III $1.136(0.818,1.578) \quad 0.446 \quad 1.274 \quad 0.149$ $(0.917,1.772)$

Health Center II $\quad 0.736(0.386,1.402) \quad 0.351 \quad 1.143 \quad 0.700$ $(0.579,2.254)$

$\begin{array}{lllll}\text { Private Health } & 0.249(0.036,1.752) & 0.163 & 0.301 & 0.238\end{array}$

Unit

$(0.041,2.213)$

Others

$3.849(1.579,9.385) \quad 0.003$

Religion

$\begin{array}{lll}\text { Catholic } & \text { Ref } & \\ \text { Anglican / } & 1.259(0.942,1.682) & 0.119 \\ \text { Protestant } & & \\ \text { Moslem } & 0.802(0.516,1.246) & 0.326 \\ \begin{array}{l}\text { Pentecostal / } \\ \text { Born Again }\end{array} & 0.996(0.649,1.531) & 0.987 \\ \text { Evangelical } & & \\ \text { SDA } & 0.248(0.035,1.732) & 0.160 \\ \text { Others } & 1.487(0.246,9.013) & 0.666\end{array}$

ART

$\begin{array}{lll}\text { No } & \text { Ref } & \\ \text { Yes } & 3.775 & 0.178 \\ & (0.546,26.110) & \end{array}$

Duration on ART

$\begin{array}{lll}0 & \text { Ref } & \\ 1 & 1.325(0.767,2.288) & 0.313 \\ 2 & 1.479(0.874,2.501) & 0.144\end{array}$

Table 6 Correlates of use of safer conception methods (Continued)

Distribution of women, in HIV care, aged 15-49 who report that they have ever used any safer conception methods (TUI, MSI, PrEP) to reduce HIV transmission by selected background characteristics

\begin{tabular}{|c|c|c|c|c|}
\hline \multirow{2}{*}{$\begin{array}{l}\text { Background } \\
\text { characteristic }\end{array}$} & \multicolumn{2}{|l|}{ Bivariate } & \multicolumn{2}{|l|}{ Multivariate } \\
\hline & $\mathrm{PR}(95 \% \mathrm{Cl})$ & $p$-value & $\mathrm{PR}(95 \% \mathrm{Cl})$ & $p$-value \\
\hline $3+$ & $1.474(0.929,2.338)$ & 0.100 & & \\
\hline \multicolumn{5}{|l|}{ Marital status } \\
\hline Married & Ref & & & \\
\hline Not married & $1.177(0.883,1.569)$ & 0.266 & & \\
\hline
\end{tabular}

Disclosed HIV status to partner

\begin{tabular}{lllll} 
No & Ref & \multicolumn{2}{c}{ Ref } & \\
Yes & $3.416(1.776,6.570)$ & 0.001 & 2.613 & 0.007 \\
& & & $(1.308,5.221)$ &
\end{tabular}

Partner's HIV Status

$\begin{array}{lllll}\text { Positive } & \text { Ref } & & \text { Ref } & \\ \text { Negative } & 1.426(1.076,1.889) & 0.013 & 1.637 & 0.001 \\ & & & (1.236,2.168) & \\ \text { Don't know } & 0.583(0.392,0.866) & 0.008 & 0.906 & 0.646 \\ & & & (0.595,1.380) & \end{array}$

Partner ART status

Yes Ref

No $\quad 1.408(0.812,2.439) \quad 0.223$

Don't know $\quad 0.685(0.227,2.063) \quad 0.501$

Education

$\begin{array}{lll}\text { No education } & \text { Ref } & \\ \text { Primary } & 1.056(0.710,1.570) & 0.788 \\ \text { Secondary } & 0.877(0.561,1.372) & 0.566 \\ \text { More than } & 1.206(0.555,2.622) & 0.636 \\ \text { secondary } & & \end{array}$

Number of biological children

$\begin{array}{lll}0 & \text { Ref } & \\ 1 & 1.086(0.683,1.726) & 0.727 \\ 2 & 1.047(0.694,1.581) & 0.826 \\ 3 & 0.685(0.416,1.128) & 0.137 \\ 4+ & 1.096(0.756,1.589) & 0.629\end{array}$

Pregnant with an intended pregnancy or intends to have a child in two years

\begin{tabular}{|c|c|}
\hline Yes & Ref \\
\hline No & $1.102(0.768,1.583)$ \\
\hline
\end{tabular}

General awareness of Safer Conception

\begin{tabular}{lllll} 
No & Ref & \multicolumn{2}{c}{ Ref } & \\
Yes & $1.838(1.238,2.727)$ & 0.03 & 2.953 & $<0.001$
\end{tabular}

Knowledge of any one Safer Conception method

$$
\begin{array}{lll}
\text { No } & \text { Ref } \\
\text { Yes } & 0.977(0.747,1.279) & 0.868
\end{array}
$$

Knowledge Categories of Safer Conception 
Table 6 Correlates of use of safer conception methods (Continued)

Distribution of women, in HIV care, aged 15-49 who report that they have ever used any safer conception methods (TUI, MSI, PrEP) to reduce HIV transmission by selected background characteristics

\begin{tabular}{|c|c|c|c|c|}
\hline \multirow{2}{*}{$\begin{array}{l}\text { Background } \\
\text { characteristic }\end{array}$} & \multicolumn{2}{|l|}{ Bivariate } & \multicolumn{2}{|l|}{ Multivariate } \\
\hline & PR(95\% Cl) & $p$-value & PR(95\% Cl) & $p$-value \\
\hline $\begin{array}{l}\text { Knew only one } \\
\text { method }\end{array}$ & Ref & & & \\
\hline $\begin{array}{l}\text { Knew two } \\
\text { methods }\end{array}$ & $1.126(0.798,1.590)$ & 0.497 & & \\
\hline $\begin{array}{l}\text { Knew three to } \\
\text { four methods }\end{array}$ & $0.733(0.461,1.168)$ & 0.192 & & \\
\hline
\end{tabular}

and find no need to use another method. Although we did not assess use of viral suppression as a safer conception method since guidelines on viral suppression as an SCM had not been rolled out in Uganda, it calls for a need to promote viral suppression both as a prerequisite for use of other SCM but also as a method on its own when one's viral load becomes sustainably suppressed. Available evidence shows that viral suppression can effectively be used as a safer conception method [31]. Further, only a third of women knew that having an undetectable viral load reduces risk of HIV transmission. This calls for more effort in counseling women and couples on risk prevention, and supporting them to fully understand that HIV viraemia is the strongest risk factor for HIV transmission.

Our study had several limitations. While we acknowledge that women may have several reasons why they do not use safer conception, we did not explore these reasons. Similarly, we did not engage in a more rigorous assessment of comprehensive knowledge of the various aspects of safer conception and SCM which would be key in the implementation of the intervention. We also think that as we were assessing knowledge, respondents may have thought that it is normative to just respond "yes it is true" meaning that 'they have knowledge' without giving prior thought to their answers, this could partly explain why we have high levels of knowledge with low SCM use in some regions and low levels of knowledge with high SCM use in other regions. This highlights a need for further research to have a more rigorous assessment of the extent to which knowledge influences use of SCM as well as establish the availability of safer conception services. However the demonstrated very low levels of basic knowledge of SCM and use of safer conception in a large sample of women with high fertility and unprotected sex, is a clear indication of the gap and need to integrate these services both in HIV and family planning services. Previous research has shown that where there is increased availability, of safer conception services, SCM use increases [32].
The other limitation is that this study was conducted among HIV positive women who were in HIV care rather than among all HIV positive women. HIV positive women who are not in HIV care may have different levels of knowledge of safer conception in general and SCM in particular. In addition, we did not include HIV-positive men and HIV negative women at risk of HIV. These are important groups to consider when providing safer conception services and we recommend that further studies and programs include HIV positive women (regardless of their HIV care status), HIV-positive men and HIV negative women at risk of HIV.

Lastly with the growing evidence that sustained viral suppression translates into no viral transmission [31], it would have been of great value to assess how adherent to ART women were (those who were on ART), how this influenced their knowledge and SCM use and how many of them relied on ART and viral suppression as their safer conception strategies. However, we did not assess this since information on viral suppression as a safer conception strategy was not readily available in Uganda at the time of the study.

\section{Conclusion}

Our study found low knowledge and use of safer conception methods among HIV positive women, a population where almost half get pregnant after HIV-positive diagnosis. We found that being in a discordant relationship and having disclosed HIV status to one's sexual partner were associated with higher levels of knowledge and use of safer conception methods. Collectively, these findings suggest a need for improved sensitization about the safer conception methods, use of innovative ways to integrate safer conception into routine family planning, sexual and reproductive health services and HIV care services at health facilities. Efforts to improve HIV status disclosure as well as support those in HIV-discordant relations who desperately need safer sex solutions will increase availability and uptake of safer conception methods. There is need to fast track the development and roll out of national guidelines on implementation of safer conception and a more concerted regional effort to have safer conception part of basic HIV care.

A French translation of this article has been included as Additional file 1 (see Additional file 1).

A Portuguese translation of the abstract has been included as Additional file 2 (see Additional file 2).

\section{Additional files}

Additional file 1: Translation of this article into French (PDF $405 \mathrm{~kb}$ )

Additional file 2: Translation of the abstract of this article into Portuguese (PDF $101 \mathrm{~kb}$ ) 


\section{Abbreviations}

ART: Antiretroviral therapy; Cl: Confidence interval; FP: Family planning; HC: Health Centre; IQR: Inter quartile range; MSI: Manual self insemination; PLHIV: People Living with HIV; PR: Prevalence ratio; PrEP: Pre-exposure prophylaxis; SCM: Safer conception methods; SD: Standard deviation; SRH: Sexual and Reproductive Health; SSA: Sub-Saharan Africa; TASO: The AIDS Support Organization; TUI: Timed Unprotected Intercourse

\section{Acknowledgements}

We acknowledge the support received from the $\mathrm{MOH}$ and MakSPH management, the district and facility managers, as well as the clients who participated in this study.

\section{Funding}

This research was funded by the Uganda Ministry of Health through a Grant from the Global Fund and UNFPA. Publication of this article was sponsored by UNFPA. The funders had no role in study design, data collection and analysis, decision to publish, or preparation of the manuscript. The journal supplement is made possible by the generous support of the American People through the United States Agency for International Development (USAID) in partnership with United Nations Population Fund (UNFPA) and The Joint United Nations Program on HIV/AIDS (UNAIDS). The views expressed in this publication are solely the opinions of the authors and do not necessarily reflect the official policies of the USAID, UNFPA or UNAIDS, nor does mention of the department or agency names imply endorsement by the U.S. Government, UNFPA or UNAIDS.

\section{Availability of data and materials}

The dataset(s) supporting the conclusions of this article is (are) available upon request and permission from UNFPA, Uganda Ministry of Health and the Makerere University Institutional Review Board.

\section{About this supplement}

This article has been published as part of Reproductive Health, Volume 16 Supplement 1, 2019: Effective Integration of Sexual Reproductive Health and HIV Prevention, Treatment, and Care Services across sub-Saharan Africa: Where is the evidence for program implementation? The full contents of the supplement, published as a joint collaboration between Reproductive Health and BMC Public Health, are available online at https://reproductive-healthjournal.biomedcentral.com/articles/supplements/volume-16-supplement-1 and https://bmcpublichealth.biomedcentral.com/articles/supplements/volume-19-supplement-1

\section{Authors' contributions}

$V G$, JBK, JBB, JKBM, SM, JA, JB, DK, RK, FM and RKW, initiated the topic, developed the proposal and coordinated the data collection. JBB and FM analyzed the data. VG wrote the first draft of the manuscript. All authors participated in the interpretation of the data, reviewed and approved the final manuscript.

\section{Ethics approval and consent to participate}

Ethical approval for this study was obtained from Makerere University School of Public Health Higher Degrees, Research and Ethics committee and the Uganda National Council for Science and Technology. Permission to conduct the study was also obtained from district and facility managers. Participants were anonymous and provided informed written consents that were detached from the questionnaire. Participants received 5,000 Uganda shillings (US\$ 1.5) as compensation for their time per the IRB approval. Sexually active adolescents (15-17 years) were handled as emancipated minors, with a waiver of the parental/guardian consent, based on the national research guidelines [33].

\section{Consent for publication}

Not applicable.

\section{Competing interests}

The authors declare that they have no competing interests.

\section{Publisher's Note}

Springer Nature remains neutral with regard to jurisdictional claims in published maps and institutional affiliations.

\section{Author details}

${ }^{1}$ Makerere University School of Public Health, Kampala, Uganda. ${ }^{2}$ Department of Obstetrics and Gynecology, Mulago National Referral Hospital, Kampala, Uganda. ${ }^{3}$ Ministry of Health, Kampala, Uganda. ${ }^{4}$ UNFPA, Kampala, Uganda. ${ }^{5}$ RAND Corporation, Santa Monica, CA, USA.

Published: 29 May 2019

\section{References}

1. Uganda Demographic and Health Survey 2016. https://www.ubos.org/ onlinefiles/uploads/ubos/pdf\%20documents/Uganda_DHS_2016_KIR.pdf (2017). Accessed 1 Aug 2018.

2. Uganda Population-based HIV impact assessment UPHIA 2016-2017. https://www.scribd.com/document/356607702/UPHIA-Uganda-Factsheet (2017). Accessed 2 Aug 2018.

3. Beyeza-Kashesya J, Ekstrom AM, Kaharuza F, Mirembe F, Neema S, Kulane A. My partner wants a child: a cross-sectional study of the determinants of the desire for children among mutually disclosed sero-discordant couples receiving care in Uganda. BMC Public Health. 2010;10:247.

4. Kakaire $\mathrm{O}$, Osinde M, Kaye DK. Factors that predict fertility desires for people living with HIV infection at a support and treatment Centre in Kabale, Uganda. Reprod Health. 2010;7:27.

5. Wagner G, Linnemayr S, Kityo C, Mugyenyi P. Factors Associated with Intention to Conceive and its Communication to Providers Among HIV Clients in Uganda. Matern Child Health J. 2012;16(2):510-8.

6. Wanyenze RK, et al. Uptake of family planning methods and unplanned pregnancies among HIV infected individuals: a cross-sectional survey among clients at HIV clinics in Uganda. J Int AIDS Soc. 2011;14:35.

7. Beyeza-Kashesya J, Kaharuza F, Mirembe F, et al. The dilemma of safe sex and having children: challenges facing HIV sero-discordant couples in Uganda. African Health Services. 2009;9:2-12.

8. Uganda Ministry of Health. Uganda AIDS Indicator Survey 2011. https:// dhsprogram.com/pubs/pdf/AlS10/AIS10.pdf. Accessed 12 Nov 2017.

9. Allen S, Meinzen-Derr J, Kautzman M, Zulu I, Trask S, Fideli U, et al. Sexual behavior of HIV discordant couples after HIV counseling and testing. AIDS 2003;17(5):733-40.

10. Tadesse M. Assessment of HIV discordance and associated risk factors among couples receiving HIV test in Dilla, Ethiopia. BMC Res Notes. 2014;7:893.

11. Brubaker SG, Bukusi EA, Odoyo J, et al. Pregnancy and HIV transmission among HIV-discordant couples in a clinical trial in Kisumu, Kenya. HIV Med. 2011;12(5):316-21.

12. UNICEF. Count down to zero: elimination of new HIV infections among children by 2015 and keeping their mothers alive (Uganda). https://data. unicef.org/wp-content/uploads/country_profiles/Uganda/PMTCT_UGA.pdf (2012). Accessed 27 Jul 2018.

13. Joint United Nations Programme on HIV/AIDS (UNAIDS) special analysis, 2017. Ending AIDS Progress towards the 90-90-90 targets. http://www. unaids.org/sites/default/files/media_asset/Global_AIDS_update_2017_en.pdf (2017). Accessed 1 Aug 2018.

14. Black V, Davies N, Williams BG, Rees HV, Schwartz SR. Establishing conception intentions and safer conception services for eliminating the vertical, and reducing the horizontal, transmission of HIV. BJOG. 2016;123: 1585-1588.

15. Fakoya A, Lamba H, Mackie N, et al. British HIV Association, BASHH and FSRH guidelines for the management of the sexual and reproductive health of people living with HIV infection 2008. HIV Med. 2008;9:681-720.

16. Centers for Disease Control and Prevention. Revised guidelines for HIV counseling, testing, and referral. MMWR Recomm Rep. 2001;50(RR-19):1-57.

17. Loutfy MR, Margolese S, Money DM, Gysler M, Hamilton S, Yudin MH. Canadian HIV pregnancy planning guidelines: no. 354, January 2018. Int J Gynaecol Obstet. 2018;40(1):94-114.

18. Bekker L-G, Black V, Myer L, Rees H, Cooper D, Mall S, Mnyami C, Conradie F, Mahabeer I, Gilbert L, Schwartz S. Guideline on safer conception in fertile HIV-infected individuals and couples. S African J HIV Med. 2011;12(2):31-44.

19. Finocchario KS, Wanyenze R, Mindry D, Beyeza KJ, Goggin K, Nabiryo C, Wagner G. "I may not say we really have a method, it is gambling work": knowledge and acceptability of safer conception methods among providers and HIV clients in Uganda. Health Care Women Int. 2014;35(0):896-917.

20. Schwartz SR, Mehta SH, Taha TE, Rees HV, Venter F, Black V. High pregnancy intentions and missed opportunities for patient-provider communication 
about fertility in a south African cohort of HIV-positive women on antiretroviral therapy. AIDS Behav. 2012;16:69-78.

21. Beyeza-Kashesya J, Wanyenze RK, Goggin K, Finocchario-Kessler S, Woldetsadik MA, Mindry D, Birungi J, Wagner GJ. Stigma gets in my way: factors affecting client-provider communication regarding childbearing among people living with HIV in Uganda. PLoS One. 2018;13(2):e0192902.

22. Agadjanian V, Hayford SR. PMTCT, HAART, and childbearing in Mozambique: an institutional perspective. AIDS Behav. 2009;13(Suppl 1):103-12.

23. Cooper D, Moodley J, Zweigenthal V, et al. Fertility intentions and reproductive health care needs of people living with HIV in Cape Town, South Africa: implications for integrating reproductive health and HIV care services. AIDS Behav. 2009;13(Suppl 1):38-46

24. Goggin K, Mindry D, Beyeza-Kashesya J, et al. "Our hands are tied up": current state of safer conception services suggests the need for an integrated care model. Health Care Women Int. 2014:35(0):990-1009.

25. Moodley J, Cooper D, Mantell JE, Stern E. Health care provider perspectives on pregnancy and parenting in HIV-positive individuals in South Africa. BMC Health Serv Res. 2014;14:384.

26. Wagner G, Woldetsadik MA, Beyeza-Kashesya J, Goggi K, Mindry D, Finocchario-Kessler S, Khanakwa S, Wanyenze RK. Multi-level correlates of safer conception methods awareness and attitudes among Ugandan HIV clients with fertility intentions. Afr J Reprod Health. 2016;20(1):40-51.

27. Wagner G, Goggi K, Mindry D, Beyeza-Kashesya J, Finocchario-Kessler S, Woldetsadik MA, Khanakwa S, Wanyenze RK. Correlates of use of timed unprotected intercourse to reduce horizontal transmission among Ugandan HIV clients with fertility intentions. AIDS Behav. 2015;19(6):1078-88.

28. Finocchario-Kessler S, Mabachi N, Dariotis JK, Anderson J, Goggin K, Sweat M. "We weren't using condoms because we were trying to conceive": the need for reproductive counseling for HIV-positive women in clinical care. AIDS Patient Care STDs. 2012;26(11):700-7.

29. Steiner RJ, Dariotis JK, Anderson JR, Finocchario-Kessler S. Preconception care for people living with HIV: recommendations for advancing implementation. AIDS. 2013;27(Suppl 1):S113-9.

30. Goggin K, Finocchario-Kessler S, Staggs V, Woldetsadik MA, Wanyenze RK, Beyeza-Kashesya J, Mindry D, Khanakwa S, Wagner GJ. Attitudes, knowledge, and correlates of self-efficacy for the provision of safer conception counseling among Ugandan HIV providers. AIDS Patient Care STDs. 2015; 29(12):651-60

31. Mmeje O, Cohen CR, Cohan D. Evaluating safer conception options for HIVSerodiscordant couples (HIV-infected female/HIV-uninfected male): a closer look at vaginal insemination. Infect Dis Obstet Gynecol. 2012;587651:7.

32. Ngure K, Kimemia G, Dew K, Njuguna N, Mugo N, Celum C, Baeten JM, Heffron R. Delivering safer conception services to HIV serodiscordant couples in Kenya: perspectives from healthcare providers and HIV serodiscordant couples. J Int AIDS Soc. 2017;20(Suppl 1):21309.

33. Uganda National Council for Science and Technology (UNCST). National Guidelines for Research involving Humans. 2017. https:/www.uncst.go.ug/ guidelines-and-forms/. Accessed 28 Feb 2018.

Ready to submit your research? Choose BMC and benefit from:

- fast, convenient online submission

- thorough peer review by experienced researchers in your field

- rapid publication on acceptance

- support for research data, including large and complex data types

- gold Open Access which fosters wider collaboration and increased citations

- maximum visibility for your research: over $100 \mathrm{M}$ website views per year

At $\mathrm{BMC}$, research is always in progress.

Learn more biomedcentral.com/submissions 